IZA DP No. 9350

The Impact of Rural-Urban Migration on the Health of the Left-behind Parents

Xiang Ao

Dawei Jiang

Zhong Zhao

September 2015 


\title{
The Impact of Rural-Urban Migration on the Health of the Left-behind Parents
}

\author{
Xiang Ao \\ Renmin University of China \\ Dawei Jiang \\ Renmin University of China \\ Zhong Zhao \\ Renmin University of China \\ and IZA
}
Discussion Paper No. 9350
September 2015

\author{
IZA \\ P.O. Box 7240 \\ 53072 Bonn \\ Germany \\ Phone: +49-228-3894-0 \\ Fax: +49-228-3894-180 \\ E-mail: iza@iza.org
}

\begin{abstract}
Any opinions expressed here are those of the author(s) and not those of IZA. Research published in this series may include views on policy, but the institute itself takes no institutional policy positions. The IZA research network is committed to the IZA Guiding Principles of Research Integrity.

The Institute for the Study of Labor (IZA) in Bonn is a local and virtual international research center and a place of communication between science, politics and business. IZA is an independent nonprofit organization supported by Deutsche Post Foundation. The center is associated with the University of Bonn and offers a stimulating research environment through its international network, workshops and conferences, data service, project support, research visits and doctoral program. IZA engages in (i) original and internationally competitive research in all fields of labor economics, (ii) development of policy concepts, and (iii) dissemination of research results and concepts to the interested public.
\end{abstract}

IZA Discussion Papers often represent preliminary work and are circulated to encourage discussion. Citation of such a paper should account for its provisional character. A revised version may be available directly from the author. 
IZA Discussion Paper No. 9350

September 2015

\section{ABSTRACT \\ The Impact of Rural-Urban Migration on the Health of the Left-behind Parents*}

Since the reform and opening up in 1978, China has begun a period of rapid industrialization and urbanization. Along with an increasing number of rural people migrating to urban area for jobs, there are a considerable number of elderly parents left behind in the rural area. The impact of migration of the adult children on the health of their left-behind parents is ambiguous. On the one hand, the additional income from the children's jobs can allow their parents to afford better health care and nutrition; on the other hand, the migration necessarily reduces the amount of time the children have to take care of their parents. This paper uses the Rural Urban Migration in China data to empirically investigate the effect of adult children's migration on the health of the left-behind parents. Based on a linear probability model with instrumental variable correction, we find that having one additional adult child migrated to an urban area increases the probability of the left-behind elderly parents being in poor health condition by about $8 \%$. Furthermore, parents having only one child, from low-income households, or aged above 60 years are affected more. Our results point out that the parents with only one child is the most vulnerable group and highlight the importance of establishing a formal care system for the rural elderly to complement the traditional family care in rural China.

JEL Classification: $\quad$ O15, J14, I15

Keywords: left-behind parents, health, rural-urban migration, China

Corresponding author:

Zhong Zhao

School of Labor and Human Resources

Renmin University of China

59 Zhongguancun St.

Beijing 100872

China

E-mail: mr.zhong.zhao@gmail.com

\footnotetext{
${ }^{*}$ We are very grateful for comments from Belton M. Fleisher (editor), Klaus F. Zimmermann (guest editor), Max Tani (guest co-editor), three anonymous referees, Ben Elsner, Juliane Scheffel and participants at the Conference on Advances in Methodology and Applications: Bio-demography and Multistate Event History Analysis on Healthy Aging and the $10^{\text {th }}$ IZA/World Bank Conference on Employment and Development. The collection of the Rural Urban Migration in China (RUMiC) data used in this paper is financed by IZA, ARC/AusAid, the Ford Foundation, and the Ministry of Labor and Social Security of China. Zhong Zhao would like to acknowledge financial support from the Natural Science Foundation of China (Grant No. 71173227 and No. 71233001).
} 


\section{Introduction}

According to the 2000 Chinese census, $10.5 \%$ and $7 \%$ of the Chinese population are aged above 60 and 65, respectively, and China has become an aging society. The problem of aging is especially challenging in rural China. Between the 2000 and 2010 censuses, the aging population (age above 60 ) increased by $4 \%$ in rural China, compared with $2 \%$ in urban areas. In 2012, 194 million Chinese were older than 60, and they accounted for $14.3 \%$ of the total population; of these, 117 million were in rural China, and accounted for $17 \%$ of the total rural population (see Cai et al, 2012; Wu, 2013).

Traditionally, rural China has relied on the family for old age support, partly due to the lack of a social safety network and partly due to cultural tradition.

Along with the aging population, China has also been experiencing rapid urbanization. The share of urban population increased from $18 \%$ in 1978 to $46 \%$ in 2008 . By the end of 2008, there were a total of 140 million rural-to-urban migrant workers; in 2014, this number increased to 168 million. The massive rural-to-urban migration inevitably has deepened the aging problem (Kuhn, 2001), eroded the foundation of traditional family support, and led to the presence of millions of left-behind parents in the rural areas. There were about 40 million such parents according to a news report in 2011 (Xinhua News Agency, 2011). ${ }^{1}$

Studying how the migration of the adult children affects the well-being of their left-behind parents is an important task. ${ }^{2}$

In principle the effect is ambiguous. On the one hand, the children who have

\footnotetext{
${ }^{1}$ Xinhua News Agency is a state-run news agency and one of the most authoritative news sources in China.

${ }^{2}$ In the literature, there are a handful of studies on the left-behind children in China, e.g. Zhang et al. (2014) on cognitive achievements, Zhao et al. (2014) and Zhou et al (2014) on education and school performance, and $\mathrm{Mu}$ and De Brauw (2015) on nutrition of the left-behind children, but there are almost no studies on the left-behind parents in rural China.
} 
migrated to the city to work can remit money back home and positively affect the health of the left-behind parents (e.g., Stark and Bloom, 1985; Vanwey, 2004). Kuhn et al (2011) find that the children's migration indeed has a positive effect on their parents in Indonesia, but a simulation by Antman (2013) shows a migrated child does not necessarily improve the financial condition of the parents.

On the other hand, the rural-to-urban migration also has several possible negative effects on the health of the left-behind parents. One negative channel is through the classical model of time allocation (Becker, 1965; Grossman, 1972), i.e., the emigrated children have less time to take care of their parents. Another one is migration estranges parents and children (Hermalin and Myers, 2002), and thus makes the children less likely to take care of their parents (Kuhn, 2001). Both will worsen the health of the left-behind parents. A series of studies by Antman (2010, 2012, and 2015) indeed find such negative effect. The negative effect can be due to reduced time allocation to take care of the leftbehind parents, as well as due to the increased the psychic cost of their left-behind parents resulting from their children's emigration.

In this paper, using a rich data set, the Rural Urban Migration in China (RUMiC), we empirically investigate the impact of rural-to-urban migration on the health of the leftbehind parents. Our approach here is similar to that of Antman (2010, 2015), who studied how the migration of the children from Mexico to the United States affected their leftbehind parents.

One potential obstacle to establishing the causal effect of children's migration on the health of their parents is reverse causality. Giles and $\mathrm{Mu}$ (2007) found that the health of the parents affects their children's migration decision in China. To address this issue, 
we rely on the instrumental variable approach to correct for simultaneity bias.

We use self-reported health status (SHS) as the main measurement in this study; in addition, we explore the mental health as well as illness of the left-behind parents.

Our results suggest that having adult children who migrated to an urban area significantly increases the probability of the left-behind elderly parents being in poor health condition; one additional migrated adult child increases the probability of his or her parents' being in poor SHS significantly, by about $8 \%$. Furthermore we find that parents who are from low-income households, or are more than 60 years old are affected more.

In particular, we find that the parents with only one child are the most vulnerable group. The SHS of these parents is $43.7 \%$ more likely to be poor if their only child migrates. Risk-sharing in a larger household, the tendency of bigger families to have someone at home to take care of the parents, and the siblings' interaction in migration decision as discussed in Stohr (2015) are possible explanations. Because of the family planning policy, the size of this group is likely to increase very rapidly. Household size in the rural China has decreased from 3.61 in 2004 to 3.19 in 2013. This highlights the importance of establishing a formal care system for the rural elderly to complement the traditional family care in rural China.

Our results also show that the migration of adult children adversely affects the mental health of the parents, but not the illness of the left behind parents.

The remainder of the paper is as follows: Section 2 introduces the institutional background; Section 3 describes the data and main variables; Section 4 outlines the econometric framework, discusses our choice of instrumental variables, and presents empirical results; and Section 5 concludes the paper. 


\section{Institutional Background}

China started economic reform in1978 and it has enjoyed rapid economic growth for more than three decades, but there is still significant segregation between rural and urban population. This segregation has been legally enforced by the household registration (Hukou) system since the 1950s, and was intensified in the 1960s following the failure of the Great Leap Forward and the devastating famine in the late 1950s. The more profound reason behind this segregation was the Chinese government's urbanbiased and heavy-industry-biased development strategy beginning in the 1950s. The farmers were considered by the government as an important resource to facilitate this distorted macro policy, and it was necessary to tie them to the land to provide cheap agricultural products to the industrial sector and urban areas (see Lin, Cai, and Li, 1994).

This segregation generated striking disparity between rural and urban population in multi-dimensions. Figure 1 shows significant income difference between rural and urban people. The ratio of urban to rural per capita income was about 2.6 in 1978 and increased to around 3.3 in 2010.

\section{----Figure 1----}

Besides income, the rural population in China does not enjoy the same level of other social benefits. Two notable benefits are health care insurance and pension.

Before the economic reforms, a village-based Cooperative Medical Scheme (CMS) covered 90 percent of rural residents and was their primary channel for accessing basic health care services. Along with the economic reform since 1978 and the transition from the collective commune system to the "household responsibility system", the CMS collapsed in most rural areas because it lost its main financial support from the collective 
commune welfare fund. The health insurance coverage rate dropped dramatically from $90 \%$ in 1980 to $5 \%$ in 1985 (Liu and Cao, 1992). Since then, most rural residents have remained uninsured. This situation did not change until the Chinese government began to implement a nationwide project known as the New Cooperative Medical Scheme (NCMS) in rural China in 2003. By 2010, the NCMS covered 835.6 million rural residents, nearly two-thirds of the Chinese population. Though the health insurance coverage in rural area has increased drastically, the objective of the NCMS is to provide low-cost basic health care services, and the benefit level is considerably lower than its urban counterpart.

During the 1950s through the 1970s, China's formal pension scheme mainly covered urban workers, while the rural residents did not have any pension coverage and mainly depended on their families for old-age support (Shi, 2006). This situation remained basically unchanged until 2009; there were over 90 percent of the rural elderly did not have any pension coverage in 2007 (Shen and Williamson, 2010). Aiming at providing basic social security for rural residents, the government launched a nationwide rural pension program, the New Rural Pension Scheme (NRPS), in 2009. The program rolled out very quickly, and by 2012, it covered all counties. The pension benefit varies by county, but a national guideline stipulates that the basic benefit is only 55 Chinese Yuan (about 9 US Dollar) per month, which is obviously quite low. ${ }^{3}$

As a consequence of the segregation, the yearly average migration rate for China was only 0.24 , compared with world average of 1.84 from 1950 to 1990 (Zhao, 2000). The urbanization process was severely hindered: at $11.7 \%$ in 1949 and only increased by less than $3 \%$ to $14.5 \%$ in 1978 (Wu, 1994).

After the China economic reform, the Household Responsibility System (HRS)

\footnotetext{
${ }^{3}$ Both the NCMS and the NRPS are voluntary programs.
} 
eventually replaced the collective production-team system. The HRS returned some degree of personal freedom to the rural people, increased their productivity, led to the availability of food in the urban free market, and generated surplus labor in rural areas (Zhao, 1999).

In the urban areas, the creation and development of the special economic zones, the expansion of the non-state sector and the loosening of the urban employment policy created the demand for migrants (Meng and Zhang 2001). The shift of the development strategy from capital-intensive industries towards more labor-intensive industries has also created more jobs in the urban areas.

All of these factors made the migration from rural to urban possible and necessary. Since the mid and late 1980s, rural to urban migration became a constant social phenomenon. The exact number is disputable (see, e.g. Rozelle, et al, 1999), but numbers cited in Sicular and Zhao (2002) indicate that the quantity of rural to urban migration doubled between late 1980s and mid 1990s, where in 1989 the migrants were 8.9 million and in 1994 increased to 23.0 million. Cai (1996) estimated that there were 34.1 million migrants based on the 1990 census. According to the National Bureau of Statistics, by the end of 2008, there were a total of 225 farmer-turned-workers, and among them 140 million were migrant workers, i.e. not commuting between home and workplace.

\section{Data and Key Variables}

\section{Data Set}

The data set used in this paper is the Rural Urban Migration in China (RUMiC), which is a joint scientific endeavor by the Australian National University, University of Queensland, Beijing Normal University, and Institute for the Study of Labor (IZA). The 
RUMiC survey includes 8000, 5000, and 5000 rural, urban, and migrant households, respectively. More detailed information on this survey can be found in Akgüc, Giulietti, and Zimmermann (2014).

For the purpose of this study, we use the first two waves of the survey and restrict our study sample to rural households. The first two waves of the survey conducted in 2008 and 2009. Depend on the variables, some of them are based on the information of previous year, such as health insurance status of the family members, other variables are on current state, e.g. self-reported health status. The survey of the rural sample covers eight provinces (Jiangsu, Zhejiang, Guangdong, Hebei, Hubei, Anhui, Henan, and Sichuan), plus one provincial-level municipality (Chongqing). Though it is not a national sample, this rural sample is representative of the rural population in these nine provincial areas, and these areas are the main labor-force-exporting areas in China. .

In our study sample, we restrict ourselves to the households containing both adult children and parents, and we focus on the household heads and their spouses; we further restrict the sample to parents whose age is above 50 and delete observations with key missing variables. The main sample includes 3,169 households and 5,391 parents.

\section{Dependent Variable}

Measurement of health status is crucial for our research. In the literature, there are many measures, including quality-adjusted life years (see Cutler and Richardson, 1997), disability-adjusted life years (see World Bank, 1993), and the quality of well-being scale (see Kaplan and Anderson, 1988). Field and Gold (1998) provide an excellent survey. In this paper, we construct health measures from the second wave of the RUMiC data. We use the SHS as our main measurement. In the survey, it is determined by the following 
question:

"Your current state of health (compared to people at the same age as you)

(1) Excellent (2) Good (3) Average (4) Poor (5) Very Poor"

Compared with continuous measures, this indicator has several advantages. First, the SHS is a composite indicator that can reflect health status more comprehensively. Second, though this measure is not perfect, many studies have shown that the SHS can effectively predict mortality, loss of functional ability, sick leave, and other objective health indicators (Mossey and Shapiro, 1982; Kaplan and Camacho, 1983; Idler and Kasl, 1995). Third, the SHS is simple and easy to obtain. Currently, in a developing country like China, it is difficult to obtain detailed data to construct other comprehensive health indicators. Fourth, one advantage of categorical measures is that in some degree they can mitigate the measurement error problem, since only order matters. Notable studies using the SHS include Case, Lubotsky, and Paxson (2000) and Currie and Stabile (2003).

Panel A of Figure 2 shows the corresponding frequency distributions separately for parents with and without migrating adult children. We can see that the SHSs of the parents without migrating children are better.

----Figure 2----

In order to facilitate quantitative analysis, interpretation and further mitigate measurement error, following the practice of $\mathrm{Li}$ and $\mathrm{Zhu}$ (2006), we further group the SHS into two categories, namely, we treat "Excellent" and "Good" as one category and code it to 0, and treat "Average", "Poor", and "Very Poor" as the other category, and code it to $1 .{ }^{4}$ The distribution based on the two categorical SHSs is shown in panel B of

\footnotetext{
${ }^{4}$ We also experimented with ordered probit and LPM models based on the original five categorical SHS, and the results are qualitatively similar.
} 
Figure 2. As in panel A, the parents without migrating children have better SHSs. ${ }^{5}$

Besides the above main measurement, we also investigate two additional health measurements. One is mental health. For the mental health, we based on the 12 questions of the General Health Questionnaire and use the Likert scoring method. The lowest score is 12 and highest is 48, and the higher score indicates poorer mental health.

The other is the illness of the left behind parents. This measure is directly from the following question in the survey:

"Were you sick or injured in the last three months? (including chronic or acute disease) (1) Yes (2) No"

We use " 1 " indicate Yes and " 0 " No in the paper.

\section{Independent Variables}

Our independent variables are from the first wave of the RUMiC. The key independent variable is the number of migrated adult children in the household. ${ }^{6} \mathrm{~A}$ migrant is defined as an person aged above 18 who migrated for more than three month for the purpose of work or doing business in 2007. Besides that variable, the health of the parents could be affected by many other factors. In order to avoid bias from omitted variables, we control a rich set of variables in our empirical models. Table 1 presents descriptive statistics for these key variables.

----Table 1----

We first include the personal characteristics of the parents. The variables include age and its square, gender, marital status, level of education, health insurance status, and

\footnotetext{
${ }^{5}$ As in Figure 2, the binary SHS in Table 1 also shows that parents with migrating children have worse health.

${ }^{6}$ Our definition of left-behind parents differs from the one in Connelly and Maurer-Fazio (2015). We treat parents with 1 or more migrant adult children as left-behind parents, disregard if there are still other family members remain in the household or not. So their approach highlights binary scenario, and our approach captures marginal effect from one additional migrant adult child.
} 
labor market variables. Age captures the depreciation of the health capital of the parents. Education is an important contributor to health, as discussed in Grossman (1972): a higher level of education may be beneficial to health production. Health insurance allows insured individuals to reduce their health expenditure and to improve their health status through the input of health care.

The second group of controls is household characteristics. This group of variables includes household size, household income, and number of grandchildren in the household. Household size may reflect the degree of risk and resource sharing within the household. Following the study of Gertler et al. (1987), we also include per capita household income as an explanatory variable, since the average household income is less sensitive to individual health status than individual income, and in any case it is hard to calculate individual income in rural China. Grandchildren are possible able to provide companionship to the left-behind parents and alleviate their loneliness, so we include the number of grandchildren in the model. In this part, we also have information on the types of toilet. We divide the toilets into three types: flush toilet, dry latrine, and no toilet in the household.

The last group of variables we control for is village-level variables. The first category is health accessibility, and for this purpose we use whether the village has a medical facility, such as medical station, private clinics, or a doctor. The second category is the sanitary environment of the village, viz., the type of drinking water source. We have five categories: running water, deep well water, shallow well water, river \& lake, and others.

Finally, we control for lagged health status from the first wave; and we include 
the provincial dummies to control for province-level fixed effects. ${ }^{7}$

\section{Instrumental Variables}

As discussed before, the health of the parents might affect the migration decision of their children (Giles and $\mathrm{Mu}, 2007$ ). In order to address the bias arising from this simultaneity, we apply an instrumental linear probability model (IV-LPM) as our main empirical approach.

We choose the interaction of migration probability at village level with the number of adult male children in the household as our instrumental variable, and will discuss the rationale for this choice in next section.

\section{Empirical Strategy and Results}

\section{Empirical Strategy}

Since our main dependent variable is a binary SHS, our analysis is based on a linear probability model (LPM): ${ }^{8}$

$$
\text { health }_{i}=\alpha+\beta M_{i}+X_{i} \gamma+\varepsilon_{i}
$$

where $\varepsilon_{i}$ is a random error. In our data, we observe Health $h_{i}$, a binary SHS of the parents; Health $_{i}=1$ indicates poor health, and 0 good health. $M_{i}$ is the variable of our interest; it is the number of migrant adult children in the household, and its coefficient $\beta$ captures the marginal effect of one additional child's migration on the health status of the leftbehind parents.

$X_{i}$ are other control variables as discussed in the previous section, including the characteristics of the parents, the household, the community, lagged health status, and

\footnotetext{
${ }^{7}$ We do not control for village dummies, instead we control for a host of village characteristics, since there are too many villages; and the coefficients of the village characteristics are also informative.

${ }^{8}$ We also estimate IV-Probit model, and the results are similar. Compared with IV-Probit model, the coefficients of the LV-LPM directly reflect marginal effect and are easy to interpret.
} 
provincial fixed effects. The SHS was measured in the second wave, and the number of migrant adult children was measured in the first wave.

\section{The Choice of the Instrumental Variables}

To address the possibility of reverse causality, we apply the IV method, and our main results are based on an IV-LPM model.

It is important to discuss how we choose the IVs. The IVs should be significantly correlated with $M_{i}$, the number of migrant adult children in the household, but have no correlation with $\varepsilon_{i}$. One possible IV is migration probability at the village level. As suggested by Mansuri (2006), we choose the interaction of the village-level migration probability with the number of adult male children in the household as the IV. The rationale of our choice is as follows.

First, we note that many studies have found that social networks are closely related with the migration behavior of the household members. For examples, Massey et al (1993) pointed out that the social network can provide useful information on the destination of potential migrant workers; Munshi (2003) demonstrated that the social network can improve the economic return of migrant workers; theoretical work by CalvoArmengol and Jackson (2004) shows that the social networks can reduce migration and job search costs; All these studies indicate that the social network increases the probability of migration. The RUMiC data, the data set used in this paper, also shows that about half of the migrants find their job through social network. Therefore, for households in a village with a richer experience of migration, their members will have a higher probability of migration.

Following the practice in the literature, utilizing a village-level survey in the 
RUMiC, we construct a variable which measures the proportion of the adult migrants in the village as our IV. This IV surely is correlated with the number of migrant adult children in a household, but is unlikely to correlate with the health of the parents at the individual household level.

Second, although our IV is unlikely to correlate with unobserved household characteristics, it is possible that it correlates with health status at the village level as well as with unobserved village characteristics. To solve this problem, we need to construct an IV which varies across villages as well as across households. To construct an IV varying with households, we look at the characteristics of the households. In rural China, women generally take care of the household chores, and men are more likely to participate in farm activities. If the household has only one adult male, he is unlikely to migrate to an urban area. In fact, among the households with only one adult male, only $40 \%$ have lost one or more members to migration, compared with more than $50 \%$ of households have migrant household members for the whole sample.

Nonetheless, for a valid IV, we also need to know that the number of adult male children in the household is not correlated with the health status of the parents. In Table 2, we informally test if this argument is supported by the data. The results show that after controlling other household characteristics, the number of adult males has no effect on the SHS of their parents.

\section{----Table 2----}

Last, as Bound, Jaeger, and Bake (1995) pointed out, it is necessary to test whether an IV is weak or not, since weak IVs can do more harm than good in a finite sample. Table 3 is the first stage of our estimation, and it shows that our IV has a 
significant positive effect on the number of migrated children in the household. The $F$ statistics are well above 10; this indicates that weak IV is not a problem in this study.

\section{----Table 3----}

However, we admit that the validity of the exclusion restriction of an IV is impossible to test. In the migration literature, another often used IV for migration decision is some exogenous shocks at village level, such as rain fall; however, in our research context such shock is likely to directly affect the well-being, e.g. health status, of the left-behind household members, and is unlikely to be valid.

Giles and $\mathrm{Mu}$ (2007) find that the poor health of the parents negatively affects the rural-to-urban migration decision of their children. Given their finding, the OLS estimates in our paper are downward bias. After correcting the bias, we find that our IV estimates are consistent with Giles and $\mathrm{Mu}$ (2007) reversed causality story.

\section{Main Results and Robustness}

In this section, we summarize our main findings. Table 4 presents estimates from both PLM and IV-PLM models. The key variable is the number of adult migrant children, as discussed before.

\section{----Table 4----}

The effects of the key variable are significantly positive for both LPM and IVLPM models (columns 1 and 3). Remember that 1 indicates a worse SHS, so the results show that migration has a negative effect on the health of the left-behind parents. One migrant adult child increases the likelihood that the parents' SHS is bad by 2 or 8 percent, depending on the model. It is possible that this effect depends on the number of adult children in the household, and we will discuss this issue in the next section. 
After closely examining the estimates from both models, we find that the one from the LPM model is smaller ( $2 \%$ compared with $8 \%$ ), which is consistent with the reserve causality story. ${ }^{9}$ The result from the IV-LPM is less significant, which is marginally significant at $5 \%$ level. This is not surprising, since IV estimation generally results in larger standard errors.

Among the other important factors, we find that the role of education is in general insignificant, except the ones with 14-year of education and above. One possible reason is that the education level of the old population in the rural area does not vary much.

Marital status and age are not important, either. There is a considerable gender effect. A mother is $4 \%$ more likely than a father to be in bad health (columns 1 to 4 ); however, the interaction term between female and the number of adult migrant children is insignificant (columns 5 to 8).

Both higher per capita income of the household and a bigger household are associated with better health of the parents. For the former, it is likely that the richer household can afford better health care. For the latter, one possible rationale is that the bigger the household, the more able it is to share risk and to alleviate a negative health shock; at the same time, in a bigger household, even if a child has migrated to the urban area, it is more likely that there is someone to take care of the left-behind elderly.

In Appendix Table 1, we experiment different specifications. This exercise serves two purposes. One is to check if the results from our base model are robust; the other is to examine if the children's migration affects their parents' health through the household income.

\footnotetext{
${ }^{9}$ The significant $2 \%$ estimated from the OLS can be treated as the lower bound of the impact of the adult children's migration on the health of the left-behind parents.
} 
First, we exclude household per capita income from the control variables (columns 3 and 4). The estimated coefficient of the number of migrant children remains virtually unchanged compared with the base model (see columns 1 and 2, which is copied from columns 3 and 4 of Table 4). It might imply that the additional household income from the children's migration is not an important channel. ${ }^{10}$

Next, we exclude working status of the parents alone (columns 5 and 6), working status plus the household per capita income (columns 7 and 8). Results from these two specifications are very similar to one from our base model.

Last, we exclude working status of the parents, household per capita income and household size (columns 9 and 10). The estimate remains significant but somehow decreases a bit.

\section{Heterogeneous Effects}

Our main results show that there are considerable differential effects between females and males and along the dimensions of household size and household income. In this section, we look into the heterogeneous effects on several important dimensions: gender, age, household size, income level, and whether a parent is a household head or not. These results are summarized in Table 5, and we focus on the estimates from IVPLM.

\section{----Table 5----}

Panel A shows results separately by male and female. Though in the pooled regression the mother is more likely to be associated with bad health, the results based on separated samples do not show significant differences between mother and father. One

\footnotetext{
${ }^{10}$ In Appendix Table 2, we investigate the association of the children's migration and the household per capita income. The result shows that an additional adult child migrant is associated with less than $2 \%$ increase in the household per capita income. Of course, we should not interpret this association as causality.
} 
explanation is the gender difference does not go through the children's migration channel, as shown in columns (5) and (7) in Table 4, the interaction term between female and the number of adult migrant children is insignificant.

In our main regression the age effect is insignificant, and this is counterintuitive. To further explore the role of age, in panel B we divide the sample into two parts: the ones with age below 60 and the rest. The results are very different. Having an additional child migrated has no significant effect on the SHS of the younger left-behind parents, but significantly increases (by 17.8\%) the likelihood for the older ones (age above 60) to have poor health status. This is reasonable. First, the relatively young parents are likely to be still in good health and able to do some household chores, so that the migration of their children may have little impact on their health. If parents are relatively old, they are more likely to be in bad health and need to be cared for by their children, and then the impact may be more significant.

Now we turn to the role of family size. As discussed earlier, first, the bigger a household is, the more able it is to share risk and mitigate negative health shocks. Second, in the bigger household, even if some child has migrated to the urban area, there is still someone at home to take care of the elderly in the household (also see the discussion in Antman, 2012 and Stohr, 2015). In panel C we divide the sample into parents with only one child and with more than one child. The results are strikingly different. For the parents with only one child, the migration of the only child significantly affects the health of the left-behind parents; the SHS of these parents is $43.7 \%$ more likely to be poor. But for the parents with more than one child, the migration of their children has insignificant effect. This finding has important policy implications. Because of the family planning 
policy, the size of parents with only one child is likely to increase very rapidly. From 1978 to 2013, the national household size has decreased from 4.66 to 3.03, and household size in the village has decreased from 3.61 in 2004 to 3.19 in 2013, see Figure $3 .{ }^{11}$ It is important and urgent to establish old age support system to complement the traditional family care in rural China, though the traditional family-based support still plays an important role in rural China (Cheng et al. 2015).

----Figure 3----

It is possible that the income level of the household also plays a role. For example, a rich household can hire someone to take care of the left-behind parents if the adult children are away, and this will alleviate the impact of children's migration on the health of the parent. In order to explore this issue, we divide the households into two groups according to the median per capita income. Panel $\mathrm{C}$ indeed shows that the parents from the lower-income households suffer more. However, when we interpret this result, we should note that the household income is an endogenous variable itself, and can be influenced by the migration of the household members.

Last, we investigate if the household head plays a role. A household head may play a leading role and share more responsibility in the household. If an adult child migrates out, the left-behind household head needs to share more burdens than her/his spouse, and this could adversely affect her/his health more. In panel $\mathrm{E}$, we find that the household head in fact suffers more health loss.

Overall, our results suggest that the migration of the adult children has larger adverse effects on parents who are older, have only one child, are from a poor household,

\footnotetext{
${ }^{11}$ The household size was 4.33 in 1953, kept increasing and peaked at 5.05 in 1975, and started to decrease from then on. The initial increasing was likely due to the baby boom after the end of the civil war.
} 
or act as a household head.

\section{Other Health Measures}

Besides the SHS, we also examine the relationship between children's migration and parental health using other measures. One is mental health, which is based on the 12 questions of the General Health Questionnaire. Using the same data set, Akay et al. (2012) applies this measurement to study the subjective-well being of the rural-to-urban migrants. The other is a binary variable indicates if an observation was sick or injured in the last three months.

\section{----Table 6----}

Table 6 summarizes the results based on these two measurements. From both OLS and IV-PLM, we can see that the children's migration and parents' mental health have a significantly negative relation at $10 \%$ level. This is consistent with the story of Antman (2015). However, there is no significant effect of children's migration on the sickness of their parents. One possible reason is that it take longer time for the children's migraing having an impact on the physical health of their parent.

\section{Conclusions}

Using the rural sample of the RUMIC data, we apply IV-LPM model to investigate if the adult children's migration adversely affects the health of their parents.

After correcting possible bias from reverse causality, we find that having children migrated to urban area indeed increases the probability of the left-behind elderly parents being in poor health: one additional migrated adult child increases that probability by about $8 \%$. Though in theory it is possible that a migrated child can improve the health of his/her parents by send back more money, our study suggest that having someone at 
home to take care of the elderly is more important, especially for poor households.

The above argument is also supported by our heterogeneous effects analysis. After dividing the sample into parents with only one child and with more than one child, we find that only the parents with one child suffer significantly; the SHS of these parents is $43.7 \%$ more likely to be poor if their only child migrates. Risk-sharing in a larger household, the tendency of bigger families to have someone at home to take care of the parents, and the siblings' interaction decision are possible explanations. This result shows that the parents with only one child are the most vulnerable group. Because of the family planning policy, the size of this group is likely to increase very rapidly, and that highlights the importance of establishing formal care for the rural elderly to complement the traditional family care in rural China. 


\section{References}

Akay A, Bargain, O. \& Zimmermann, K. (2012). "Relative Concerns of Rural-to-Urban Migrants in China," Journal of Economic Behavior and Organization, 81(2), 421441.

Akgüç, M., Giulietti, C. \& Zimmermann, K.F. (2014). “The RUMiC Longitudinal Survey: Fostering Research on Labor Markets in China," IZA Journal of Labor \& Development, 3:5.

Antman, F. M. (2010). "Adult Child Migration and the Health of Elderly Parents Left Behind in Mexico," American Economic Review, 100(2), 205-208.

Antman, F. M. (2012). "Elderly Care and Intra-family Resource Allocation when Children Migrate," Journal of Human Resources, 47(2), 331-363.

Antman, F. M. (2013). "The Impact of Migration on Family Left Behind," in International handbook on the Economics of Migration, eds. A. F. Constant and K. F. Zimmermann, Edward Elgar: Northampton, MA.

Antman, F. M. (2015). "How Does International Migration Affect the Health of Elderly Parents Left Behind? Evidence from Mexico," Department of Economics, University of Colorado at Boulder, unpublished manuscript.

Becker, G. S. (1965). "A Theory of the Allocation of Time," The Economic Journal, 75, 493-517.

Bound, J., Jaeger, D.A. \& Baker, R.M. (1995). "Problems with Instrumental Variables Estimation When the Correlation between the Instruments and the Endogenous Explanatory Variable is Weak," Journal of the American Statistical Association, 90 (430), 443-450.

Cai, F. (1996). "Laodongli qianyi he liudong de jingjixue fengxi" [An economic analysis for labor migration and mobility]. Zhongguo shehuikexue jikan (Spring): 120-35.

Cai, F., Giles, J., O'Keefe, P. \& Wang, D. (2012). “The Elderly and Old Age Support in Rural China: Challenges and Prospects" The World Bank.

Calvo-Armengol, A. \& Jackson, M.O. (2004). "The Effects of Social Networks on Employment and Inequality," The American Economic Review, 94(3), 426-454.

Case, A., Lubotsky, D. \& Paxson, C. (2002). "Economic Status and Health in Childhood: The Origins of the Gradient," American Economic Review, 92(5), 1308-1334. 
Cheng, L., Liu, H., Zhang, Y. \& Zhao, Z. (2015). “The Heterogeneous Impact of Pension Income on Elderly Living Arrangements: Evidence from China's New Rural Pension Scheme," IZA Discussion Paper No. 9116.

Connelly, R. \& Maurer-Fazio, M. (2015). "Left Behind, At Risk, and Vulnerable Elders in Rural China: What the RUMIC Data Reveal about the Extent, Causes, and Consequences of Being Left Behind," IZA Discussion Paper No. 9213.

Currie, J. \& Stabile, M. (2003). "Socioeconomic Status and Child Health: Why Is the Relationship Stronger for Older Children?” American Economic Review, 93(5), 1813-1823.

Cutler, D. M. \& Richardson, E. (1997). "Measuring the Health of the U.S. Population," Brookings Papers on Economic Activity: Microeconomics 1997, 217-271.

Field, M. J. \& Gold, M. R. (1998). Summarizing Population Health: Directions for the Development and Application of Population Metrics, Washington D.C., USA: National Academy Press.

Gertler, P., Locay, L., \& Sanderson, W. (1987). “Are User Fees Regressive? The Welfare Implications of Health Care Financing Proposals in Peru," Journal of Econometrics, 36(1-2), 67-88.

Giles J. \& Mu, R. (2007). "Elderly Parent Health and the Migration Decision of Adult Children: Evidence from Rural China,” Demography, 44(2), 265-288.

Grossman, M. (1972). "On the Concept of Health Capital and the Demand for Health," Journal of Political Economy, 80(2), 223-255.

Hermalin, A. I. \& Myers, L.G. (2002). "Aging in Asia: Facing the Crossroads,” In A.I. Hermalin (Ed.). The Well-Being of the Elderly in Asia: A Four Country Comparative Study, 1-23. Ann Arbor, MI: University of Michigan Press.

Idler, E. L. \& Kasl, S.V.(1995). "Self-Ratings of Health: Do They Also Predict Change in Functional Ability?" Journal of Gerontology, 50, 344-353.

Li , H. \& Zhu, Y. (2006). "Income, Income Inequality, and Health: Evidence from China," Journal of Comparative Economics, 34(4), 668-693.

Lin, J., Cai, F. \& Li, Z. (1994), The Chinese Miracle: Development Strategy and Economic Reform, Shanghai Sanlin Publish House and Shanghai People's Publishing House, Shanghai. 
Liu, X. \& Cao, H. (1992). “China's Cooperative Medical System: Its Historical Transformations and the Trend of Development," Journal of Public Health Policy, 13(4), 501-511.

Kaplan, R. \& Anderson, J. P. (1988). “A General Health Policy Model: Update and Applications," Health Services Research, 23(2), 203-235.

Kaplan, R. \& Camacho, T. (1983). "Perceived Health and Mortality: A Nine-Year Followup of the Human Population Laboratory Cohort," American Journal of Epidemiology, 117, 292-304.

Kuhn, R. (2001). "The Impact of Nuclear Family and Individual Migration on the Elderly in Rural Bangladesh: A Qualitative Analysis," Labor and Population Program Working Paper Series, June, 01-11.

Kuhn, R., B. Everett and R. Silvey (2011). "The Effect of Children's Migration on Elderly Kin's Health: A Counterfactual Approach,” Demography, 48(1), 183-209.

Mansuri, G. (2006). "Migration, School Attainment and Child Labor: Evidence from Rural Pakistan,” World Bank Policy Research Working Paper, No.3945.

Massey, D., Arango, J., Hugo, G., Kouaouci, A., Pellegrino, A., \& Taylor, J.E. (1993). "Theories of International Migration: A Review and Appraisal," Population and Development Review, 20(4), 699-751.

Meng, X., \& Zhang, J. (2001). “The Two-Tier Labor Market in Urban China,” Journal of Comparative Economics, 29, 485-504.

Mossey, J. M. \& Shapiro, E. (1982). "Self-Rated Health: A Predictor of Mortality among the Elderly," American Journal of Public Health, 72, 800-808.

Mu, R. and De Brauw, A. (2015). "Migration and Young Child Nutrition: Evidence from Rural China," Journal of Population Economics, 28(3), 631-657.

Munshi, K. (2003). "Networks in the Modern Economy: Mexican Migrants in the U.S. Labor Market," The Quarterly Journal of Economics, 118(2), 549-599.

Rozelle, S., Guo, L., Shen, M., Hughart, A. \& Giles, J. (1999). "Leaving China's Farms: Survey Results of New Paths and Remaining Hurdles to Rural Migration," China Quarterly, 158: 367-93.

Shen, C. \& Williamson, J. B. (2010). “China's New Rural Pension Scheme: Can it be Improved?" International Journal of Sociology and Social Policy, 30 (5/6): 239-250. 
Shi, S. J. (2006). "Left to Market and Family - Again? Ideas and the Development of the Rural Pension Policy in China," Social Policy and Administration, 40(7), 791-806.

Sicular, T., \& Zhao, Y. 2002. "Employment and Earnings in Rural China." Mimeographed. Stark, O. \& Bloom D.E. (1985). "The New Economics of Labor Migration," American Economic Review, 75, 173-178.

Stohr, T. (2015). "Siblings' Interaction in Migration Decisions: Who Provides for the Elderly Left Behind?" Journal of Population Economics, 28(3), 593-629.

Vanwey, L. K. (2004). “Altruistic and Contractual Remittances between Male and Female Migrants and Households in Rural Thailand," Demography, 41, 739-756.

World Bank (1993). World Development Report 1993: Investing in Health. Oxford, UK: Oxford University Press.

Wu, H. (1994), "Rural to Urban Migration in the People's Republic of China," China Quarterly, 139, 669-698.

Wu, Y. S. (2013). China Aging Population Development Report 2013. Beijing, China: Social Sciences Academic Press.

Xinhua News Agency. (2011). "There are about 40 Million Left-behind Elderly in Rural Area." (http://news.xinhuanet.com/politics/2011-03/01/c_121135612.htm)

Zhao, Q., Yu, X., Wang X, \& Glauben, T. (2014). "The Impact of Parental Migration on Children's School Performance in Rural China," China Economic Review, 31, 43-54.

Zhang, H., Behrman J., Fan, C., Wei, X. \& Zhang, J. (2014). "Does Parental Absence Reduce Cognitive Achievements? Evidence from Rural China," Journal of Development Economics, 111, 181-195.

Zhao, Y. (1999), "Labor Migration and Earnings Differences: The Case of Rural China," Economic Development and Cultural Change, 47, 767-782.

Zhao, Y. (2000). Rural-to-Urban Labor Migration in China: The Past and the Present, in Rural Labor Flows in China, eds. Loraine A. West and Yaohui Zhao, Institute of East Asian Studies, University of California, Berkeley.

Zhou, M, Murphy, R. \& Tao, R. (2014). "Effects of Parents' Migration on the Education of Children Left Behind in Rural China," Population and Development Review, 40(2), 273-292. 
Figure 1. Ratio of Urban to Rural per Capita Income in China

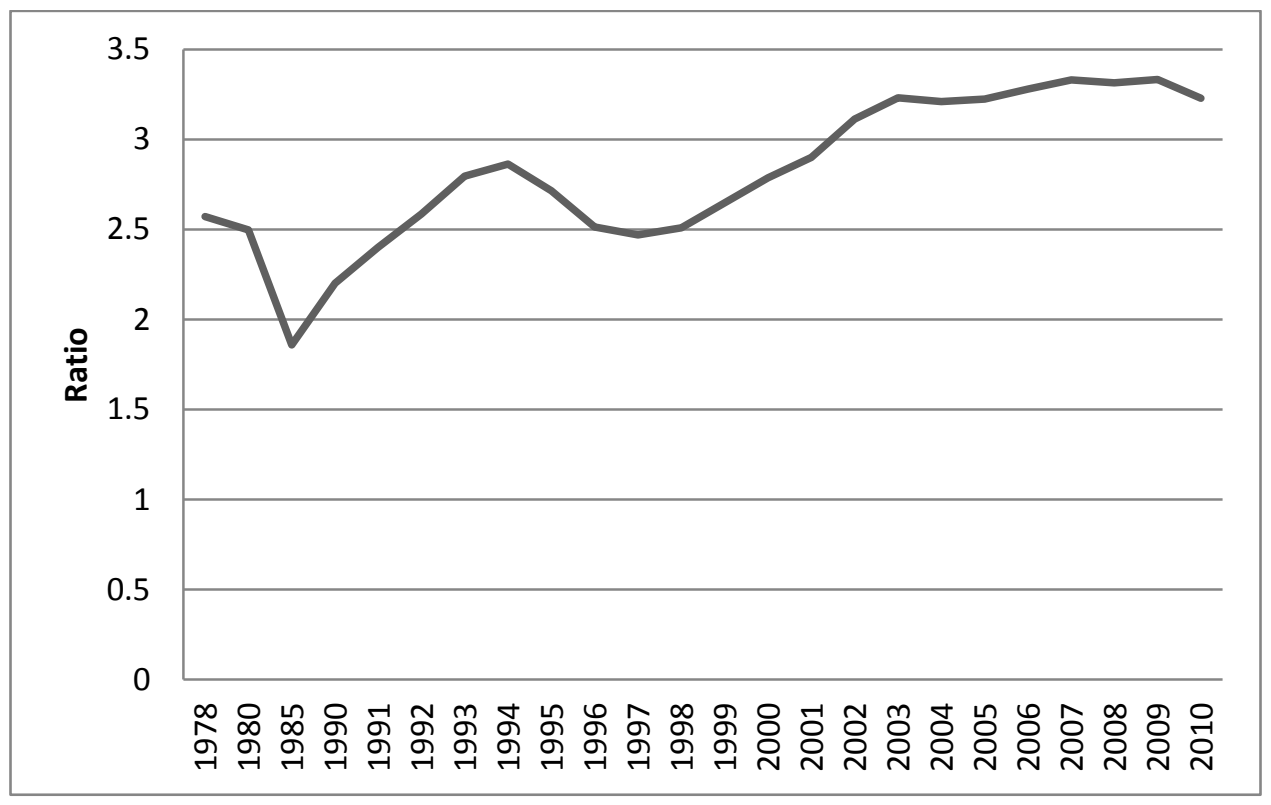

Data Source: China Statistical Year Book (2011) 
Figure 2. Self-Reported Health Status

Panel A. Self-Reported Health Status: Five Categories

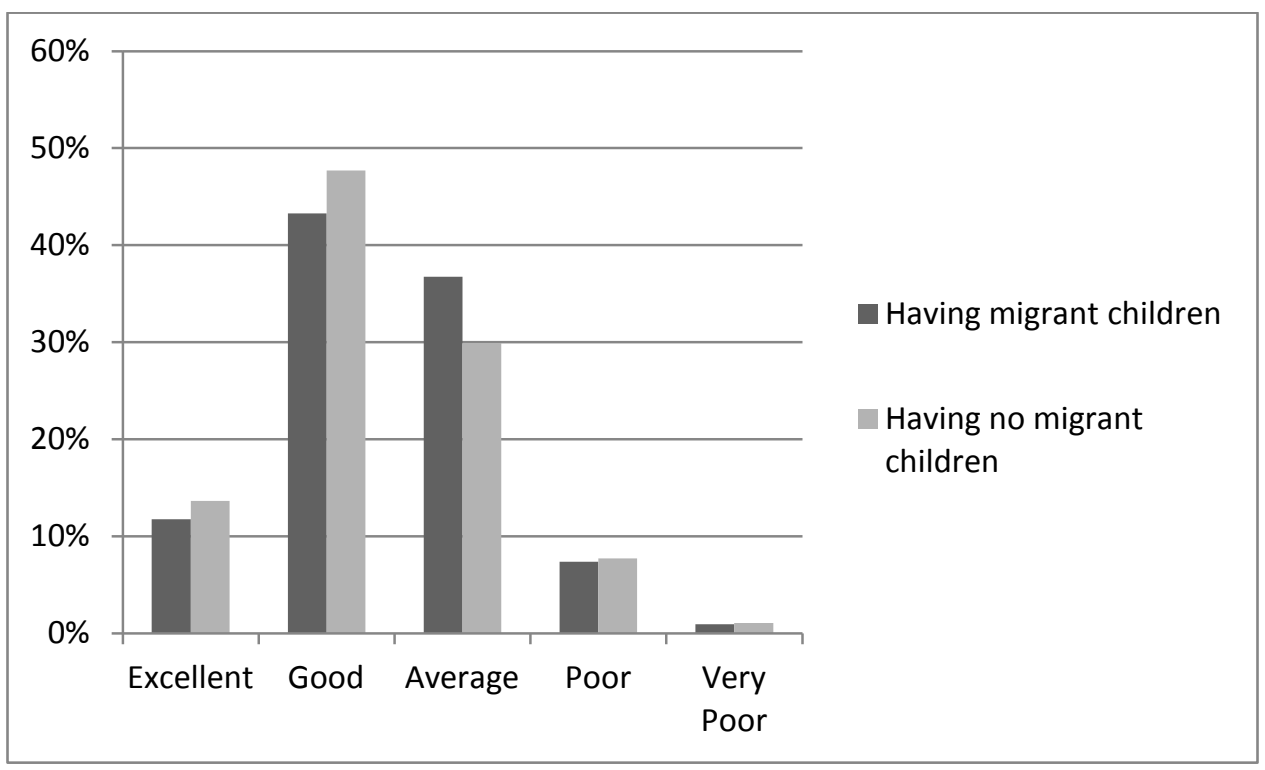

Panel B. Self-Reported Health Status: Two Categories

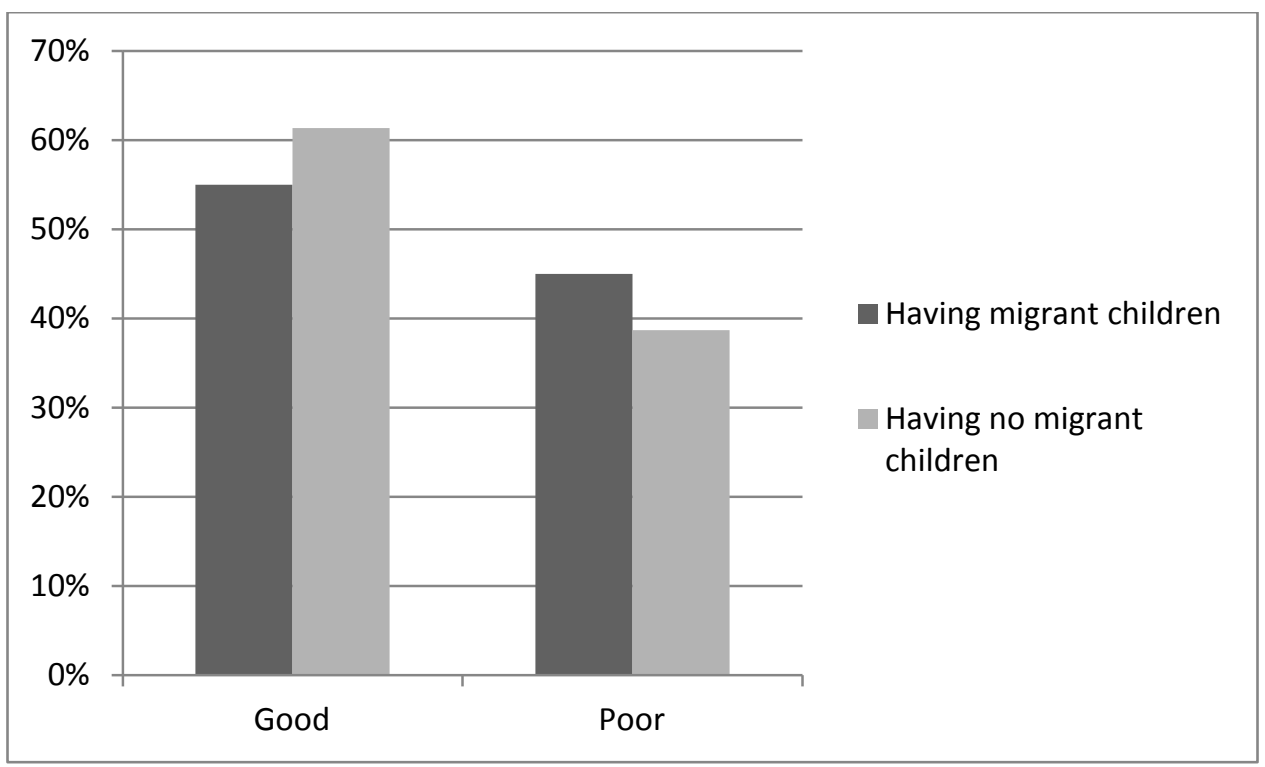

Notes: 1. Authors' calculation from the Rural Urban Migration in China Survey.

2. In panel B, we group the SHS into two categories, namely, we treat "Excellent" and "Good" as "Good", and treat "Average", "Poor", and "Very Poor" as the "Poor". 
Figure 3. Household Size in China: 1978 to 2013

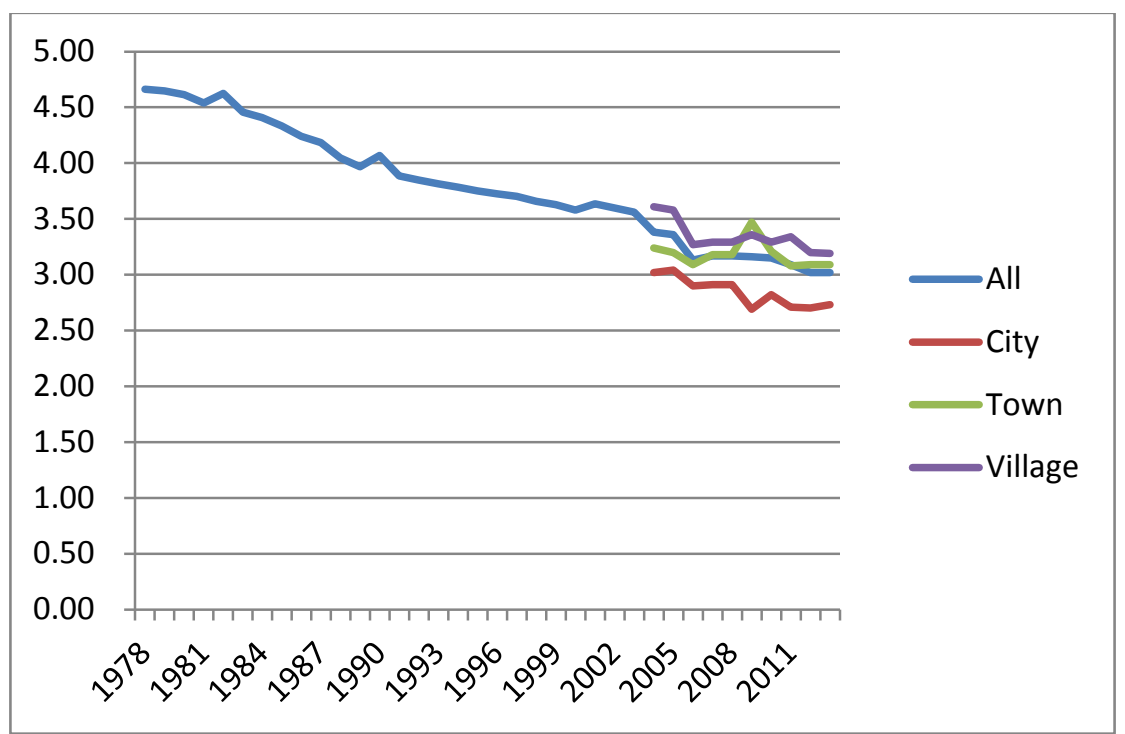

Data Sources: Data before 2004, China Population Yearbook;

Data from 2004, China Population and Employment Yearbook 
Table 1. Summary Statistics of Main Variables

\begin{tabular}{|c|c|c|c|c|c|c|c|}
\hline \multirow[b]{2}{*}{ Variables } & \multicolumn{2}{|c|}{ Total Sample } & \multicolumn{2}{|c|}{ Sample without Migrant Children } & \multicolumn{3}{|c|}{ Sample with Migrant Children } \\
\hline & Mean & Std. Dev. & Mean & Std. Dev. & Mean & Std. Dev. & \\
\hline Self-reported health status (dummy, 1 indicates poor health) & 0.419 & 0.493 & 0.387 & 0.487 & 0.450 & 0.498 & $* * *$ \\
\hline Number of migrant adult children in the household & 0.785 & 0.942 & 0.000 & 0.000 & 1.533 & 0.766 & $* * *$ \\
\hline Number of adult male $*$ Migration rate at village & 0.441 & 0.334 & 0.348 & 0.299 & 0.529 & 0.342 & $* * *$ \\
\hline Female (dummy) & 0.457 & 0.498 & 0.450 & 0.498 & 0.464 & 0.499 & \\
\hline Age & 57.337 & 5.773 & 57.402 & 6.056 & 57.275 & 5.490 & \\
\hline Age squared & 3320.855 & 707.291 & 3331.655 & 749.248 & 3310.574 & 664.874 & \\
\hline Education level: 0 years & 0.129 & 0.335 & 0.124 & 0.330 & 0.134 & 0.340 & \\
\hline $1-6$ years & 0.473 & 0.499 & 0.471 & 0.499 & 0.476 & 0.500 & \\
\hline $7-9$ years & 0.333 & 0.471 & 0.338 & 0.473 & 0.329 & 0.470 & \\
\hline $10-13$ years & 0.062 & 0.242 & 0.064 & 0.245 & 0.060 & 0.238 & \\
\hline 14 years and above & 0.002 & 0.045 & 0.003 & 0.055 & 0.001 & 0.033 & \\
\hline Married (dummy) & 0.956 & 0.206 & 0.947 & 0.224 & 0.964 & 0.186 & $* * *$ \\
\hline Have medical insurance (dummy) & 0.990 & 0.100 & 0.987 & 0.115 & 0.993 & 0.083 & $* *$ \\
\hline Working status (dummy, 1 indicates working) & 0.810 & 0.392 & 0.768 & 0.422 & 0.851 & 0.356 & $* * *$ \\
\hline Annual working days & 181.411 & 113.036 & 178.895 & 118.838 & 183.806 & 107.188 & \\
\hline Log household per capita income (Chinese Yuan per year) & 8.625 & 0.588 & 8.669 & 0.630 & 8.584 & 0.542 & $* * *$ \\
\hline Family size (number of household members) & 4.709 & 1.402 & 4.582 & 1.294 & 4.829 & 1.489 & $* * *$ \\
\hline Number of grandchildren in the household & 0.656 & 0.807 & 0.620 & 0.773 & 0.690 & 0.836 & $* * *$ \\
\hline Have health facility in village (dummy) & 0.921 & 0.269 & 0.910 & 0.286 & 0.932 & 0.252 & $* * *$ \\
\hline Toilet/latrine: Have flushing toilet (dummy) & 0.312 & 0.463 & 0.382 & 0.486 & 0.245 & 0.430 & $* * *$ \\
\hline Have dry latrine (dummy) & 0.639 & 0.480 & 0.564 & 0.496 & 0.711 & 0.454 & $* * *$ \\
\hline No toilet/latrine (dummy) & 0.049 & 0.216 & 0.054 & 0.225 & 0.045 & 0.206 & \\
\hline Water sources: Tap water (dummy) & 0.424 & 0.494 & 0.535 & 0.499 & 0.319 & 0.466 & $* * *$ \\
\hline Deep phreatic water (dummy) & 0.392 & 0.488 & 0.313 & 0.464 & 0.467 & 0.499 & $* * *$ \\
\hline Shallow phreatic water (dummy) & 0.161 & 0.368 & 0.137 & 0.344 & 0.184 & 0.387 & $* * *$ \\
\hline River/lake water (dummy) & 0.014 & 0.119 & 0.008 & 0.087 & 0.021 & 0.143 & $* * *$ \\
\hline Other water source (dummy) & 0.009 & 0.092 & 0.007 & 0.085 & 0.010 & 0.098 & \\
\hline Number of observations & & & & & & & \\
\hline
\end{tabular}

Notes: 1. Data Source: the Rural Urban Migration in China Survey. Except the self-reported health, all other variables are from the first wave.

2. Self-reported status is coded from the original five-categorical variable, and we treat "Excellent" and "Good" as one category and code it to 0, and treat

"Average", "Poor", and "Very Poor" as the other category, and code it to 1 . This variable is from the second wave of the data and refers to health status in 2009.

3. A migrant child is defined as who was older than 18 and migrated for more than three month for the purpose of work or doing business in 2007.

4. All individual level variables are for the parents; toilet type and water source type are defined at village level. Except the SHS

5. Last column indicates t-test for two-group means. ${ }^{* * *}$ Significant at $1 \%,{ }^{* *}$ Significant at $5 \%,{ }^{*}$ Significant at $10 \%$. 
Table 2. Number of Adult Males on Self-Reported Health Status of the Parents

\begin{tabular}{|c|c|c|}
\hline & (1) & (2) \\
\hline Variables & Coefficient & Standard Error \\
\hline Number of adult males in the household & -0.007 & 0.011 \\
\hline Lagged self-reported health status (dummy) & $0.431^{* * * *}$ & 0.014 \\
\hline Female (dummy) & $0.043^{* * *}$ & 0.014 \\
\hline Age & 0.010 & 0.013 \\
\hline Age squared/100 & -0.004 & 0.011 \\
\hline \multicolumn{3}{|l|}{ Reference group: No education } \\
\hline Education level 1-6 years & -0.008 & 0.020 \\
\hline Education level 7-9 years & -0.017 & 0.022 \\
\hline Education level 10-13 years & -0.023 & 0.030 \\
\hline Education level 14 years and above & $-0.236^{* *}$ & 0.098 \\
\hline Married (dummy) & 0.022 & 0.031 \\
\hline Have medical insurance (dummy) & 0.056 & 0.054 \\
\hline Working status (dummy, 1 indicates working) & -0.028 & 0.018 \\
\hline Annual working days/100 & -0.005 & 0.006 \\
\hline Log household per capita income (Chinese Yuan per year) & $-0.033^{* * *}$ & 0.011 \\
\hline Family size (number of household members) & -0.010 & 0.008 \\
\hline Number of grandchildren in the household & 0.010 & 0.013 \\
\hline Have health facility in village (dummy) & -0.030 & 0.024 \\
\hline \multicolumn{3}{|l|}{ Reference group: No toilet/latrine (dummy) } \\
\hline Flushing toilet (dummy) & 0.025 & 0.030 \\
\hline Dry latrine (dummy) & 0.020 & 0.030 \\
\hline \multicolumn{3}{|l|}{ Reference group: Other water source (dummy) } \\
\hline Tap water (dummy) & -0.041 & 0.061 \\
\hline Deep phreatic water (dummy) & -0.045 & 0.060 \\
\hline Shallow phreatic water (dummy) & -0.043 & 0.061 \\
\hline River/lake water (dummy) & 0.084 & 0.083 \\
\hline Provincial dummies & \multicolumn{2}{|r|}{ YES } \\
\hline Constant & 0.225 & 0.436 \\
\hline Adj. R-squared & \multicolumn{2}{|r|}{0.219} \\
\hline Number of observations & \multicolumn{2}{|r|}{5370} \\
\hline
\end{tabular}

Notes: $1 .{ }^{* * *}$ Significant at $1 \%,{ }^{* *}$ Significant at $5 \%,{ }^{*}$ Significant at $10 \%$.

2. For data source and variable definitions please refer to notes in Table 1. 
Table 3. First Stage

\begin{tabular}{|c|c|c|c|c|}
\hline \multirow[b]{2}{*}{ Variables } & (1) & (2) & (3) & (4) \\
\hline & Coefficient & Standard Error & Coefficient & Standard Error \\
\hline Number of adult males $\times$ Migration rate at village & $0.739^{* * * *}$ & 0.037 & $0.466^{* * * *}$ & 0.046 \\
\hline Lagged self-reported health status of the parents & & & $0.065^{* *}$ & 0.025 \\
\hline Female (dummy) & & & $0.049^{*}$ & 0.026 \\
\hline Age & & & $0.078^{* * *}$ & 0.026 \\
\hline Age squared/100 & & & $-0.062^{* * *}$ & 0.021 \\
\hline \multicolumn{5}{|l|}{ Reference group: No education } \\
\hline Education level $1-6$ years & & & 0.018 & 0.039 \\
\hline Education level 7-9 years & & & 0.042 & 0.043 \\
\hline Education level $10-13$ years & & & 0.035 & 0.063 \\
\hline Education level 14 years and above & & & $-0.475^{* * *}$ & 0.165 \\
\hline Married (dummy) & & & 0.085 & 0.053 \\
\hline Have medical insurance status (dummy) & & & $0.318^{* * *}$ & 0.104 \\
\hline Working status (dummy, 1 indicates working) & & & $0.214^{* * *}$ & 0.033 \\
\hline Annual working days/100 & & & $-0.025^{* *}$ & 0.012 \\
\hline Log household per capita income (Yuan per year) & & & $0.049^{* *}$ & 0.020 \\
\hline Family size (Number of household members) & & & $0.130^{* * * *}$ & 0.017 \\
\hline Number of grandchildren in the household & & & $-0.176^{* * *}$ & 0.030 \\
\hline Have health facility in village (dummy) & & & -0.013 & 0.042 \\
\hline \multicolumn{5}{|l|}{ Reference group: No toilet/latrine (dummy) } \\
\hline Flushing toilet (dummy) & & & 0.030 & 0.061 \\
\hline Dry latrine (dummy) & & & $0.235^{* * *}$ & 0.060 \\
\hline \multicolumn{5}{|l|}{ Reference group: Other water source (dummy) } \\
\hline Tap water (dummy) & & & -0.010 & 0.120 \\
\hline Deep phreatic water (dummy) & & & 0.185 & 0.117 \\
\hline Shallow phreatic water (dummy) & & & 0.079 & 0.118 \\
\hline River/lake water (dummy) & & & $0.594^{* * * *}$ & 0.174 \\
\hline Provincial dummies & \multicolumn{2}{|r|}{ No } & \multicolumn{2}{|r|}{ Yes } \\
\hline Constant & $0.460^{* * *}$ & 0.021 & $-3.580^{* * *}$ & 0.823 \\
\hline Number of observations & \multicolumn{2}{|c|}{5389} & \multicolumn{2}{|c|}{5370} \\
\hline F-statistics & \multicolumn{2}{|c|}{397.480} & \multicolumn{2}{|c|}{52.060} \\
\hline Adj R-squared & \multicolumn{2}{|c|}{0.069} & \multicolumn{2}{|c|}{0.214} \\
\hline
\end{tabular}

Note: $1 .{ }^{* * *}$ Significant at $1 \%,{ }^{* *}$ Significant at $5 \%,{ }^{*}$ Significant at $10 \%$.

2. For data source and variable definitions please refer to notes in Table 1. 
Table 4. Effects of Number of Migrant Children on Self-Reported Health Status of Left-behind Parents

\begin{tabular}{|c|c|c|c|c|c|c|c|c|}
\hline \multirow[b]{3}{*}{ Variables } & \multicolumn{2}{|r|}{ PLM } & \multicolumn{2}{|c|}{ IV-PLM } & \multicolumn{2}{|c|}{ PLM } & \multicolumn{2}{|c|}{ IV-PLM } \\
\hline & (1) & $(2)$ & (3) & (4) & (5) & (6) & $(7)$ & (8) \\
\hline & Coefficient & Standard Error & Coefficient & Standard Error & Coefficient & $\begin{array}{c}\text { Standard } \\
\text { Error }\end{array}$ & Coefficient & Standard Error \\
\hline Number of migrant children in the household & $0.020^{* * * *}$ & 0.007 & $0.080^{* *}$ & 0.041 & $0.012^{* *}$ & 0.009 & $0.113^{*}$ & 0.068 \\
\hline Lagged Self-reported health status & $0.429^{* * *}$ & 0.013 & $0.425^{* * *}$ & 0.014 & $0.429^{* * *}$ & 0.013 & $0.424^{* * * *}$ & 0.014 \\
\hline Female (dummy) & $0.042^{* * *}$ & 0.014 & $0.040^{* * *}$ & 0.014 & 0.028 & 0.017 & $0.097^{* *}$ & 0.049 \\
\hline Number of Migrant Children*Female & & & & & 0.018 & 0.013 & -0.073 & 0.062 \\
\hline Age & 0.009 & 0.014 & 0.004 & 0.014 & 0.009 & 0.014 & 0.002 & 0.015 \\
\hline Age squared/100 & -0.003 & 0.011 & 0.001 & 0.000 & -0.003 & 0.011 & 0.002 & 0.011 \\
\hline \multicolumn{9}{|l|}{ Reference group: No education } \\
\hline Education level 1-6 years & -0.009 & 0.020 & -0.009 & 0.020 & -0.008 & 0.020 & -0.011 & 0.020 \\
\hline Education level 7-9 years & -0.018 & 0.022 & -0.020 & 0.022 & -0.017 & 0.022 & -0.024 & 0.023 \\
\hline Education level 10-13 years & -0.023 & 0.031 & -0.025 & 0.030 & -0.022 & 0.031 & -0.030 & 0.031 \\
\hline Education level 14 years and above & $-0.227^{*}$ & 0.134 & $-0.196^{*}$ & 0.103 & $-0.228^{*}$ & 0.134 & $-0.192^{*}$ & 0.105 \\
\hline Married (dummy) & 0.022 & 0.030 & 0.019 & 0.032 & 0.022 & 0.030 & 0.017 & 0.032 \\
\hline Have medical insurance (dummy) & 0.048 & 0.060 & 0.026 & 0.057 & 0.048 & 0.060 & 0.024 & 0.057 \\
\hline Working status (dummy, 1 indicates working) & $-0.032^{*}$ & 0.017 & $-0.046^{* *}$ & 0.020 & $-0.033^{*}$ & 0.017 & $-0.041^{* *}$ & 0.019 \\
\hline Annual working days/100 & -0.004 & 0.006 & -0.002 & 0.006 & -0.004 & 0.006 & -0.001 & 0.007 \\
\hline Log household per capita income (Yuan per year) & $-0.034^{* * *}$ & 0.011 & $-0.037^{* * * *}$ & 0.011 & $-0.034^{* * *}$ & 0.011 & $-0.038^{* * *}$ & 0.011 \\
\hline Family size (number of household members) & $-0.016^{* *}$ & 0.007 & $-0.026^{* * *}$ & 0.010 & $-0.016^{* *}$ & 0.007 & $-0.027^{* * *}$ & 0.010 \\
\hline Number of grandchildren in the household & 0.017 & 0.012 & $0.029^{*}$ & 0.015 & 0.017 & 0.012 & $0.031^{*}$ & 0.016 \\
\hline Have health facility in village (dummy) & -0.028 & 0.023 & -0.025 & 0.024 & -0.029 & 0.024 & -0.024 & 0.024 \\
\hline \multicolumn{9}{|l|}{ Reference group: No toilet/latrine (dummy) } \\
\hline Flushing toilet (dummy) & 0.026 & 0.030 & 0.028 & 0.031 & 0.026 & 0.030 & 0.028 & 0.032 \\
\hline Dry latrine (dummy) & 0.016 & 0.030 & 0.005 & 0.032 & 0.016 & 0.030 & 0.0053 & 0.032 \\
\hline \multicolumn{9}{|l|}{ Reference group: Other water source (dummy) } \\
\hline Tap water (dummy) & -0.041 & 0.067 & -0.038 & 0.060 & -0.041 & 0.067 & -0.038 & 0.060 \\
\hline Deep phreatic water (dummy) & -0.049 & 0.066 & -0.061 & 0.060 & -0.049 & 0.066 & -0.061 & 0.060 \\
\hline Shallow phreatic water (dummy) & -0.045 & 0.067 & -0.050 & 0.060 & -0.045 & 0.067 & -0.050 & 0.060 \\
\hline River/lake water (dummy) & 0.071 & 0.083 & 0.033 & 0.085 & 0.072 & 0.083 & 0.032 & 0.086 \\
\hline Provincial dummies & \multicolumn{2}{|r|}{ YES } & \multicolumn{2}{|r|}{ YES } & \multicolumn{2}{|c|}{ YES } & \multicolumn{2}{|c|}{ YES } \\
\hline Constant & 0.278 & 0.445 & 0.473 & 0.465 & 0.267 & 0.445 & 0.515 & 0.476 \\
\hline Number of observations & & 5370 & & 5370 & & & & 370 \\
\hline Adj. R-squared & & 0.220 & & 0.209 & & & & 203 \\
\hline
\end{tabular}

Note: $1 .{ }^{* * *}$ Significant at $1 \%,{ }^{* *}$ Significant at $5 \%,{ }^{*}$ Significant at $10 \%$.

2. For data source and variable definitions please refer to notes in Table 1. 
Table 5. Heterogeneous Effects of Number of Migrant Children on Self-Reported Health Status of Left-behind Parents

\begin{tabular}{|c|c|c|c|c|c|}
\hline \multirow{4}{*}{ Groups } & \multicolumn{4}{|c|}{ No. of Migrant Children } & \multirow{3}{*}{$\begin{array}{c}\text { Observations } \\
(5)\end{array}$} \\
\hline & \multicolumn{2}{|c|}{ PLM } & \multicolumn{2}{|c|}{ IV-PLM } & \\
\hline & (1) & (2) & (3) & (4) & \\
\hline & Coefficient & Standard Error & Coefficient & Standard Error & \\
\hline \multicolumn{6}{|l|}{ Panel A: Gender } \\
\hline Female & $0.028^{* * * *}$ & 0.011 & 0.060 & 0.067 & 2456 \\
\hline Male & 0.011 & 0.009 & $0.091^{*}$ & 0.051 & 2914 \\
\hline \multicolumn{6}{|l|}{ Panel B: Age } \\
\hline Age 60 and Below 60 & $0.025^{\text {**** }}$ & 0.008 & 0.039 & 0.047 & 4051 \\
\hline Age above 60 & 0.004 & 0.014 & $0.178^{* *}$ & 0.084 & 1319 \\
\hline \multicolumn{6}{|l|}{ Panel C: Number of Children } \\
\hline With only one child & 0.051 & 0.031 & $0.437^{* * *}$ & 0.170 & 794 \\
\hline More than one child & $0.015^{* *}$ & 0.007 & 0.039 & 0.043 & 4554 \\
\hline \multicolumn{6}{|l|}{ Panel D: Income Level } \\
\hline Household income above the average & $0.019^{* *}$ & 0.009 & 0.062 & 0.060 & 3459 \\
\hline Household income below the average & $0.023^{* *}$ & 0.012 & $0.115^{* *}$ & 0.057 & 1911 \\
\hline \multicolumn{6}{|l|}{ Panel E: Household Head } \\
\hline Household head & 0.009 & 0.009 & $0.094^{*}$ & 0.052 & 3018 \\
\hline Spouse of Household head & $0.030^{* * *}$ & 0.011 & 0.057 & 0.066 & 2431 \\
\hline
\end{tabular}

Notes: $1 .{ }^{* * *}$ Significant at $1 \%,{ }^{* *}$ Significant at $5 \%,{ }^{*}$ Significant at $10 \%$.

2. The control variables are the same as in Table 4.

3. Samples in Panel A, B, C and E are divided by the characteristics of the parents.

4. Please refer to note in Table 1 for data source. 
Table 6. Effects of Number of Migrant Children on Mental Health and Illness of Left-behind Parents

\begin{tabular}{|c|c|c|c|c|c|c|c|c|}
\hline \multirow{4}{*}{ Variables } & \multicolumn{4}{|c|}{ Mental Health Status } & \multicolumn{4}{|c|}{ Illness } \\
\hline & \multicolumn{2}{|c|}{ OLS } & \multicolumn{2}{|c|}{ IV } & \multicolumn{2}{|c|}{ PLM } & \multicolumn{2}{|c|}{ IV-PLM } \\
\hline & (1) & $(2)$ & (3) & (4) & (5) & (6) & (7) & (8) \\
\hline & Coefficient & Std Error & Coefficient & Std Error & Coefficient & Std Error & Coefficient & Std Error \\
\hline Number of migrant children in the household & $0.124^{*}$ & 0.085 & $0.825^{*}$ & 0.674 & 0.002 & 0.005 & 0.023 & 0.029 \\
\hline Lagged mental health & $0.504^{* * *}$ & 0.015 & $0.498^{* * *}$ & 0.017 & & & & \\
\hline Lagged illness & & & & & $0.216^{* * *}$ & 0.012 & $0.213^{* * *}$ & 0.018 \\
\hline Female (dummy) & $1.099^{* * *}$ & 0.176 & $1.079^{* * *}$ & 0.186 & 0.009 & 0.010 & 0.009 & 0.010 \\
\hline Age & $-0.429^{* *}$ & 0.181 & $-0.495^{* *}$ & 0.203 & -0.003 & 0.010 & -0.005 & 0.011 \\
\hline Age squared/100 & $0.378^{* *}$ & 0.148 & $0.430^{* * *}$ & 0.166 & 0.005 & 0.008 & 0.006 & 0.009 \\
\hline \multicolumn{9}{|l|}{ Reference group: No education } \\
\hline Education level $1-6$ years & $-0.616^{* *}$ & 0.271 & $-0.626^{* *}$ & 0.308 & $-0.026^{*}$ & 0.014 & $-0.026^{*}$ & 0.015 \\
\hline Education level 7-9 years & $-0.794^{* * *}$ & 0.290 & $-0.851^{* * *}$ & 0.330 & -0.010 & 0.015 & -0.010 & 0.016 \\
\hline Education level $10-13$ years & $-0.968^{* * *}$ & 0.376 & $-1.022^{* * *}$ & 0.392 & -0.030 & 0.022 & -0.031 & 0.021 \\
\hline Education level 14 years and above & -1.301 & 1.360 & -0.971 & 1.382 & 0.018 & 0.092 & 0.029 & 0.118 \\
\hline Married (dummy) & $-0.774^{* *}$ & 0.331 & $-0.835^{* *}$ & 0.355 & 0.028 & 0.021 & 0.028 & 0.021 \\
\hline Have medical insurance (dummy) & 0.820 & 0.733 & 0.478 & 0.903 & 0.059 & 0.042 & $0.051^{*}$ & 0.028 \\
\hline Working status (dummy, 1 indicates working) & $-0.508^{* *}$ & 0.215 & $-0.653^{* *}$ & 0.285 & $-0.048^{* * *}$ & 0.012 & $-0.053^{* * *}$ & 0.015 \\
\hline Annual working days/100 & $-0.144^{*}$ & 0.075 & -0.122 & 0.078 & $-0.011^{* *}$ & 0.004 & $-0.010^{* *}$ & 0.005 \\
\hline Log household per capita income (Yuan per year) & -0.102 & 0.140 & -0.154 & 0.151 & 0.003 & 0.008 & 0.002 & 0.008 \\
\hline Family size (Number of household members) & 0.0391 & 0.086 & -0.083 & 0.138 & $-0.011^{* *}$ & 0.005 & $-0.015^{* *}$ & 0.007 \\
\hline Number of grandchildren in the household) & -0.054 & 0.151 & 0.076 & 0.193 & $0.014^{*}$ & 0.009 & $0.019^{*}$ & 0.011 \\
\hline Have health facility in village (dummy) & -0.242 & 0.279 & -0.204 & 0.288 & 0.005 & 0.016 & 0.006 & 0.016 \\
\hline \multicolumn{9}{|l|}{ Reference group: No toilet/latrine (dummy) } \\
\hline Flushing toilet (dummy) & $-0.783^{* *}$ & 0.338 & $-0.736^{* *}$ & 0.340 & -0.001 & 0.021 & -0.000 & 0.020 \\
\hline Dry latrine (dummy) & -0.119 & 0.338 & -0.235 & 0.343 & 0.020 & 0.021 & 0.016 & 0.021 \\
\hline \multicolumn{9}{|l|}{ Reference group: Other water source (dummy) } \\
\hline Tap water (dummy) & 0.005 & 0.759 & -0.019 & 0.584 & -0.003 & 0.046 & -0.002 & 0.021 \\
\hline Deep phreatic water (dummy) & 0.205 & 0.749 & 0.008 & 0.602 & -0.011 & 0.045 & -0.015 & 0.051 \\
\hline Shallow phreatic water (dummy) & 0.316 & 0.758 & 0.217 & 0.590 & -0.036 & 0.046 & -0.037 & 0.051 \\
\hline River/lake water (dummy) & 0.858 & 0.981 & 0.275 & 1.002 & -0.071 & 0.057 & -0.084 & 0.060 \\
\hline Provincial dummies & \multicolumn{2}{|c|}{ YES } & \multicolumn{2}{|c|}{ YES } & \multicolumn{2}{|c|}{ YES } & \multicolumn{2}{|c|}{ YES } \\
\hline Constant & $23.410^{* * *}$ & 5.808 & $26.640^{* * *}$ & 6.830 & 0.072 & 0.309 & 0.136 & 0.354 \\
\hline Number of observations & \multicolumn{2}{|c|}{3508} & \multicolumn{2}{|c|}{3508} & \multicolumn{2}{|c|}{5315} & \multicolumn{2}{|c|}{5315} \\
\hline Adj. R-squared & \multicolumn{2}{|c|}{0.333} & \multicolumn{2}{|c|}{0.320} & \multicolumn{2}{|c|}{0.082} & \multicolumn{2}{|c|}{0.079} \\
\hline
\end{tabular}

Note: $1 .{ }^{* * *}$ Significant at the 1 percent level, ${ }^{* *}$ Significant at the 5 percent level, ${ }^{*}$ Significant at the 10 percent level.

2. For data source and variable definitions please refer to notes in Table 1 
Appendix Table 1. Effects of Number of Migrant Children on Self-Reported Health Status of Left-behind Parents: Different Specifications for IV-PLM

\begin{tabular}{|c|c|c|c|c|c|c|c|c|c|c|}
\hline & $(\mathbf{1})$ & $(2)$ & (3) & (4) & $(5)$ & (6) & $(7)$ & (8) & $(9)$ & (10) \\
\hline Variables & Coef. & $\begin{array}{c}\text { Std } \\
\text { Error }\end{array}$ & Coef. & Std Error & Coef. & Std Error & Coef. & Std Error & Coef. & Std Error \\
\hline Number of migrant children & $0.080^{* * *}$ & 0.041 & $0.082^{* *}$ & 0.041 & $0.080^{*}$ & 0.041 & $0.082^{* *}$ & 0.041 & $0.057^{*}$ & 0.034 \\
\hline Lagged self-reported health status & $0.425^{* * *}$ & 0.014 & $0.426^{* * *}$ & 0.014 & $0.428^{* * *}$ & 0.014 & $0.430^{* * *}$ & 0.014 & $0.432^{* * *}$ & 0.014 \\
\hline Female (dummy) & $0.040^{* * *}$ & 0.014 & $0.039^{* * *}$ & 0.014 & $0.047^{* * *}$ & 0.013 & $0.047^{* * *}$ & 0.013 & $0.049^{* * *}$ & 0.013 \\
\hline Age & 0.004 & 0.014 & 0.006 & 0.014 & 0.002 & 0.014 & 0.004 & 0.014 & 0.007 & 0.014 \\
\hline Age squared/100 & 0.001 & 0.000 & -0.001 & 0.012 & 0.003 & 0.012 & 0.002 & 0.012 & -0.000 & 0.011 \\
\hline \multicolumn{11}{|l|}{ Reference group: no education } \\
\hline Education level 1-6 years & -0.009 & 0.020 & -0.011 & 0.020 & -0.008 & 0.020 & -0.010 & 0.020 & -0.010 & 0.020 \\
\hline Education level 7-9 years & -0.020 & 0.022 & -0.022 & 0.022 & -0.021 & 0.022 & -0.023 & 0.022 & -0.022 & 0.022 \\
\hline Education level 10-13 years & -0.025 & 0.030 & -0.030 & 0.030 & -0.026 & 0.030 & -0.032 & 0.030 & -0.031 & 0.030 \\
\hline Education level 14 years and above & $-0.196^{*}$ & 0.103 & $-0.209^{* *}$ & 0.104 & $-0.195^{*}$ & 0.104 & $-0.209^{* *}$ & 0.104 & $-0.219^{* *}$ & 0.100 \\
\hline Married (dummy) & 0.019 & 0.032 & 0.015 & 0.032 & 0.014 & 0.032 & 0.009 & 0.032 & 0.000 & 0.032 \\
\hline Have medical Insurance (dummy) & 0.026 & 0.057 & 0.025 & 0.057 & 0.026 & 0.056 & 0.024 & 0.056 & 0.032 & 0.056 \\
\hline Log household per capita income & $-0.046^{* *}$ & 0.020 & & & $-0.039^{* * * *}$ & 0.011 & & & & \\
\hline Working status (dummy, 1 indicates working) & -0.002 & 0.006 & $-0.046^{* *}$ & 0.020 & & & & & & \\
\hline Annual working days $/ 100$ & $-0.037^{* * *}$ & 0.011 & -0.003 & 0.006 & & & & & & \\
\hline Family size (number of household members) & $-0.026^{* * *}$ & 0.010 & $-0.022^{* *}$ & 0.010 & $-0.026^{* * *}$ & 0.010 & $-0.021^{* *}$ & 0.010 & & \\
\hline Number of grand children & $0.029^{*}$ & 0.015 & 0.028 & 0.015 & $0.029^{*}$ & 0.015 & $0.028^{*}$ & 0.015 & 0.000 & 0.009 \\
\hline Have health facility in village (dummy) & -0.025 & 0.024 & -0.030 & 0.024 & -0.035 & 0.024 & $-0.040^{*}$ & 0.023 & $-0.043^{*}$ & 0.023 \\
\hline \multicolumn{11}{|l|}{ Reference group: No toilet/latrine (dummy) } \\
\hline Flushing toilet (dummy) & 0.028 & 0.031 & 0.022 & 0.031 & 0.031 & 0.031 & 0.025 & 0.031 & 0.029 & 0.031 \\
\hline Dry latrine (dummy) & 0.005 & 0.032 & 0.003 & 0.032 & 0.004 & 0.032 & 0.002 & 0.032 & 0.010 & 0.031 \\
\hline \multicolumn{11}{|l|}{ Reference group: Other water source } \\
\hline Tap water (dummy) & -0.038 & 0.060 & -0.044 & 0.060 & -0.034 & 0.060 & -0.039 & 0.060 & -0.043 & 0.060 \\
\hline Deep phreatic water (dummy) & -0.061 & 0.060 & -0.064 & 0.060 & -0.059 & 0.060 & -0.062 & 0.060 & -0.060 & 0.060 \\
\hline Shallow phreatic water (dummy) & -0.050 & 0.060 & -0.049 & 0.061 & -0.049 & 0.060 & -0.047 & 0.060 & -0.047 & 0.060 \\
\hline River/lake water (dummy) & 0.033 & 0.085 & 0.040 & 0.085 & 0.033 & 0.085 & 0.041 & 0.085 & 0.063 & 0.084 \\
\hline Provincial dummies & \multicolumn{2}{|c|}{ YES } & \multicolumn{2}{|c|}{ Yes } & \multicolumn{2}{|c|}{ Yes } & \multicolumn{2}{|c|}{ Yes } & \multicolumn{2}{|c|}{ Yes } \\
\hline Constant & 0.473 & 0.465 & 0.095 & 0.449 & 0.496 & 0.466 & 0.094 & 0.451 & -0.076 & 0.435 \\
\hline Number of observations & \multicolumn{2}{|c|}{5370} & \multicolumn{2}{|c|}{5370} & \multicolumn{2}{|c|}{5384} & \multicolumn{2}{|c|}{5384} & \multicolumn{2}{|c|}{5384} \\
\hline Adj. R-squared & \multicolumn{2}{|c|}{0.220} & \multicolumn{2}{|c|}{0.207} & \multicolumn{2}{|c|}{0.208} & \multicolumn{2}{|c|}{0.206} & \multicolumn{2}{|c|}{0.212} \\
\hline
\end{tabular}

Notes: $1 .{ }^{* * * *}$ Significant at $1 \%,{ }^{* *}$ Significant at $5 \%,{ }^{*}$ Significant at $10 \%$.

2. Column (1) is the base results from column (2) in Table 4.

3. For data source and variable definitions please refer to notes in Table 1 
Appendix Table 2. Children's Migration and Log Household per Capita Income

\begin{tabular}{|c|c|c|c|c|}
\hline \multirow[t]{2}{*}{ Variables } & (1) & (2) & (3) & (4) \\
\hline & Coefficient & Standard Error & Coefficient & Standard Error \\
\hline Number of migrant children & $-0.031^{* * * *}$ & 0.008 & $0.017^{* *}$ & 0.008 \\
\hline Female (dummy) & & & 0.016 & 0.017 \\
\hline Age & & & $-0.050^{* * *}$ & 0.017 \\
\hline Age squared/100 & & & $0.032^{* *}$ & 0.013 \\
\hline \multicolumn{5}{|l|}{ Reference group: No education } \\
\hline Education level $1-6$ years & & & $0.056^{* *}$ & 0.024 \\
\hline Education level 7-9 years & & & $0.053^{* *}$ & 0.026 \\
\hline Education level $10-13$ years & & & $0.151^{* * *}$ & 0.037 \\
\hline Education level 14 years and above & & & $0.395^{* *}$ & 0.161 \\
\hline Married (dummy) & & & $0.106^{* * *}$ & 0.036 \\
\hline Have medical Insurance (dummy) & & & 0.009 & 0.073 \\
\hline Working status (dummy, 1 indicates working) & & & 0.007 & 0.021 \\
\hline Annual working days $/ 100$ & & & $0.039^{* * *}$ & 0.007 \\
\hline Family size (number of household members) & & & $-0.125^{* * *}$ & 0.008 \\
\hline Number of grand children in the household & & & $0.047^{* * *}$ & 0.015 \\
\hline Have health facility in village (dummy) & & & $0.128^{* * *}$ & 0.028 \\
\hline \multicolumn{5}{|l|}{ Reference group: No toilet/latrine (dummy) } \\
\hline Flushing toilet (dummy) & & & $0.161^{* * *}$ & 0.036 \\
\hline Dry latrine (dummy) & & & 0.046 & 0.036 \\
\hline \multicolumn{5}{|l|}{ Reference group: Other water source (dummy) } \\
\hline Tap water (dummy) & & & $0.149^{*}$ & 0.080 \\
\hline Deep phreatic water (dummy) & & & 0.089 & 0.080 \\
\hline Shallow phreatic water (dummy) & & & -0.032 & 0.080 \\
\hline River/lake water (dummy) & & & $-0.218^{* *}$ & 0.100 \\
\hline Provincial dummies & \multicolumn{2}{|c|}{ YES } & \multicolumn{2}{|c|}{ YES } \\
\hline Constant & $8.650^{* * *}$ & 0.010 & $10.330^{* * *}$ & 0.517 \\
\hline Number of observations & \multicolumn{2}{|c|}{5389} & \multicolumn{2}{|c|}{5370} \\
\hline Adj R-squared & \multicolumn{2}{|c|}{0.002} & \multicolumn{2}{|c|}{0.200} \\
\hline
\end{tabular}

Notes: $1 .{ }^{* * *}$ Significant at $1 \%,{ }^{* *}$ Significant at $5 \%,{ }^{*}$ Significant at $10 \%$.

2. For data source and variable definitions please refer to notes in Table 1. 